\title{
Value Creation of a Business Customer in Nature-based Tourism Service
}

\author{
By Leena Alakoski* \\ Irma Tikkanen
}

In this paper we describe the kinds of value that were created within the field of nature-based tourism service from the perspective of a host in a role of a business customer. The qualitative research was conducted by using the laddering technique based on a means- end chain model of 40 theme interviews. The findings indicated that the customer's value created in nature-based tourism includes the following: "feeling of impressiveness"; "feeling of indulging oneself, pleasure, and joy"; "feeling of beauty of nature"; "feeling of healthiness"; and "feeling of hospitality". Based on the findings, only an individual can experience and create value requiring personal evaluation. Customer value is created in the context of interactive situations, both from short-term experiences and from long-term memories and emotions linked to previous memories. The main theoretical contribution is to understand the theoretical concept of customer value, where the customer's life and previous experiences have a role in individual value creation. Other participants also have a role in one's value creation, and value is shared in an interactive process. The practical contribution helps a nature-based tourism entrepreneur develop the service and a value proposition as well as to support the customer's value creation process.

Keywords: Business customer, Customer Value, Nature-based, Service, Tourism

\section{Introduction}

The share of service sectors in the industrial structure of Finland is growing. Subsequently, the need for service research becomes important. In service marketing and service business, both business customers and consumers are seen today as active actors, not as the target of marketing activities. When the role of a customer is changing and becoming active, it will change the thinking and interpretation as well as the role of companies as buyers and users of services. That change will have an impact on the theoretical contents of customer research, too. That is why it has been necessary to develop activities towards customer-centered marketing thinking.

Many studies in service marketing have emphasized the viewpoint of a customer instead of service. The Nordic School of Services has started to use the term customer-dominant logic (CDL) (Heinonen et al., 2010; Grönroos and Voima, 2013; Grönroos and Gummesson, 1985). Because the purpose of a service company's business emphasizes attention to the customer's wishes,

\footnotetext{
* Principal Lecturer, Laurea University of Applied Sciences, Finland.

${ }^{*}$ Docent, University of Eastern Finland, Finland.
} 
then understanding the customer becomes important. Customer-centricity is also seen in the studies on customer value creation.

The research question reads as follows:

What kinds of value are created within the field of nature-based tourism service from the perspective of a host in a role of a business customer?

In this paper nature-based tourism service from the viewpoint of a business customer is related to service in tourism during working hours as a commercial service product. The viewpoint of a host representing a business customer of a nature-based tourism service provider in Finland is applied. The nature-based tourism service is provided for the companies and their customers and personnel. A business customer buys a service and a representative of a company participates in a nature-based tourism trip in the role of a host with his guests. All nature-based tourism sectors are included in a nature-based tourism service.

The concept of a customer is based on the definitions in service- and customer-centered business logic, according to which all are actors (Vargo and Lusch, 2010, 181; Gummesson, 2011, 191). This paper is based on Alakoski's (2014) doctoral dissertation.

\section{Nature-based Tourism as a Research Context}

Nature-based tourism is related to recreation and enjoying free time in nature. Nature has been a pull factor in tourism in Finland for decades (Fredman and Tyrväinen, 2010). Nature-based tourism service used by business customers may include overnighting tourism service, recreation trips in daytime, or it can be a part of local tourism. Local trips and short holidays are an increasing sector in tourism (Honkanen, 2004).

Researches describing recreation related to nature-based tourism have been conducted for at least 50 years (Raadik et al., 2010). Nature-based recreation service is related to the renewal of a body and mind. The sector is also related to wellbeing and wellbeing at work, and thus related to wellbeing tourism. Similarly, work-based tourism is related to wellbeing, by which is meant tourism service producing wellbeing even after the trip (Smith and Kelly, 2006). The outdoor activities are linked to wellbeing tourism. The means promoting working ability and wellbeing in a working community are related to the wellbeing of personnel. According to Konu (2010), wellbeing as a term includes service, the purpose of which is to take care of the total wellbeing of a body, mind, and soul. The activities paid by the companies and public organisations maintaining working ability in tourism mean activities provided outside the working place by the tourism companies (Matkailun edistämiskeskus, 2005). 
The buying decision of a nature-based service is not a routine decision in a customer company. It can be related, for example, to incentive tourism, and the typical attributes are high quality, uniqueness or special experiences and activities. The incentive travel is defined to be a modern management tool used to achieve business goals by rewarding the participants by a special travel experience. (Sheldon, 1995)

\section{Value Creation}

In the business market, either a value proposition or potential value are linked to the promises and attributes producing utility, which are provided for the customer (Bowman and Ambrosini, 2010; Grönroos and Helle, 2010). A customer-centered business logic defines value especially by the term value-inuse. It may be understood as a long-lasting value accumulating in the customer's process, be stored in mind and memories. According to a customercentered business logic, a person creates value in one's own life, which means that the focus is on an individual. (Heinonen et al., 2010).

Because value is perceived and defined by an individual based on usage and experience, value-in-use has become an important basis how to define value in service- and customer-centered dominant logic (Grönroos, 2008; Grönroos and Ravald, 2011). According to Helkkula et al. (2012), value is based on experiences in a customer-centered business logic. When value is created individually as an experience and experienced internally, it is also shared with others socially.

The creation of the customer's experience occurs in the service context and usage situations. (Verhoef et al., 2009). Interaction between a service provider and a customer, as well as interaction between participants are linked to usage situations and cooperation processes. The theoretical basis has, however, recognized that value cannot be created for the customer, but it is only able to support the value creation of the customer (Grönroos, 2011b).

Customer experience and value are examined related to life, as a cumulative reality for the customer (Heinonen et al., 2010; Helkkula et al., 2012). Table 1 describes the characteristics of value creation in a customer-centered business logic.

Customer-centered thinking also widens the thinking of relativity. Value is not only relative compared with other products and services, but relative compared with the customer's multi-contextual life. Each customer in one's own life is a part of the value creation process from one's viewpoint (Heinonen et al., 2010). Service experience and recognizing value in the process are dependent on the customer's past, present, and future. The total experience and value are dependent on the customer's internal and external factors and time space. Value creation is a kind of a process in the customer's life. (Helkkula et al., 2012) Value creation may be a passive process that is not always conscious. Through the process related to mentality and emotions the customer interprets service in the interaction either consciously or unconsciously and 
constructs again one's experience accumulating it into reality and value creation. (Heinonen et al., 2010)

Table 1. Value Creation in a Customer-centered Business Logic

\begin{tabular}{|c|c|c|}
\hline Questions & $\begin{array}{l}\text { Customer-centered } \\
\text { business logic }\end{array}$ & References \\
\hline Who & $\begin{array}{l}\text { - The customer's value is created } \\
\text { personally. } \\
\text { - Value is related to the } \\
\text { customer's life. } \\
\text { - Value is collective and shared. } \\
\text { - The customer defines what } \\
\text { value is for him/her. }\end{array}$ & Helkkula et al., 2012 \\
\hline How & $\begin{array}{l}\text { - Value is co-created in } \\
\text { cooperation with the provider } \\
\text { and a customer. } \\
\text { - It is active, but it can also be a } \\
\text { passive, unconscious process. } \\
\text { - Can also be mental and related } \\
\text { to an emotional process. } \\
\text { - Even a customer cannot } \\
\text { organize value creation. }\end{array}$ & $\begin{array}{l}\text { Grönroos, } 2008 \\
\text { Heinonen and Strandvik, } 2009 \\
\text { Heinonen } \text { et al., } 2010\end{array}$ \\
\hline Where & $\begin{array}{l}\text { - Is created either in visible or } \\
\text { invisible processes. } \\
\text { - Value is related to the } \\
\text { customer's life. } \\
\text { - Is often located in the } \\
\text { customer's uncontrollable life } \\
\text { area. }\end{array}$ & $\begin{array}{l}\text { Heinonen and Strandvik, } 2009 \\
\text { Heinonen } \text { et al., } 2010 \\
\text { Grönroos, 2011a } \\
\text { Helkkula } \text { et al., } 2012\end{array}$ \\
\hline When & $\begin{array}{l}\text { - Is long-lasting. } \\
\text { - Is dynamic in many ways. }\end{array}$ & $\begin{array}{l}\text { Grönroos, } 2008 \\
\text { Heinonen and Strandvik, } 2009 \\
\text { Grönroos, 2011a } \\
\text { Grönroos and Voima, } 2013\end{array}$ \\
\hline What & $\begin{array}{l}\text { - Is relative on many levels. } \\
\text { - New methods and tools are } \\
\text { needed. } \\
\text { - } \quad \text { The concept of value-in-use. }\end{array}$ & $\begin{array}{l}\text { Heinonen } \text { et al., } 2010 \\
\text { Helkkula } \text { et al., } 2012\end{array}$ \\
\hline
\end{tabular}

Source: c.f. Alakoski 2014, 58.

\section{Methodology}

The reason to select a means-end chain model as an interview method was that it has been used during the last thirty years when exploring value related to marketing (Gutman, 1982; Reynolds and Gutman, 1988; Gengler et al., 1999; Sondergaard, 2005). Furthermore, Woodruff's (1997, 141-142) value hierarchy model has been dominant when exploring value based on experiences. The value hierarchy model is originally related to consumer research. Although one interviewed person in the current research was a 
representative of a business customer, we may use a means-end chain model when examining value creation of a person.

According to Sondergaard $(2005,80)$, the value hierarchy model explains how the factors of choosing the service, service and product attributes, the consequences after usage, and the customer's usage experience are linked to the customer's value. An interview can be partly structured especially as to why-questions, in other words, "why is that important to you" questions (Olsen et al., 2008). An interview started and proceeded based on open questions classified by themes.

The means-end chain model has been used both as a qualitative and quantitative method. The origin of it is based on interviews, a qualitative method, that has been described as a soft means-end chain model. (Miles and Rowe, 2004; Veludo-de-Oliveira et al., 2006; Phillips and Reynolds, 2009) As a quantitative method the means-end chain model is not able to indicate value creation clearly (Pieters et al., 1995; Grunert et al., 1995). At best, a soft method will lead to rich results qualitatively. An interviewee will bring freely one's own experiences, positive or negative, and he/she may also tell things not depending on the hierarchical order. A qualitative method will encourage the interviewee to give more responses. However, a small amount of data does not provide enough validity. (Miles and Rowe, 2004) When applying the meansend chain model, the target is that all steps in a hierarchical value map will be drawn from the interviewees' responses (Wansink, 2003).

To sum up, attributes, consequences, value categories, hierarchical value chains, and hierarchical value maps created by those steps are the core concepts of the means-end chain model. The interviewed representatives of 40 companies were chosen from among the representatives of business companies and public organisations.

When analysing the interviews, a laddering technique was used, which was originally defined by Gutman (1982). The analysis by a laddering technique was composed of transcribing, listing, categorization, and analysis of results. An attempt was made to create proper and valid hierarchies from the data with the laddering technique by combining single observations of each unique pathway from an attribute to a representative's value. The total amount of interviews comprised 40 hours. MECanalyst software (skymax-dg.com/ mecanalyst), which is based on the means-end chain model, was used in the analysis. Reynolds and Gutman's (1988, 18-20) five phase working was followed: defining key distinctions to ladders, content analysis, summary of content codes, transferring data to MECanalyst software, and finally implication matrices, hierarchical value maps, and explanations.

After the interviews, the categorized data were transferred to MECanalyst software so that the conceptual model could be described as hierarchical value maps. When adding interviewed persons, a demographic profile and the content categories of laddering technique steps with content message where also added. This phase can be described as a cut-off and categorizing phase. An example of a value hierarchy model is introduced in Figure 1. 
Figure 1. A Description of a Value Hierarchy Model as an Example

\begin{tabular}{|c|l|l|l|}
\hline Attributes & \multicolumn{3}{|c|}{} \\
\hline Concrete (CA) & Service attribute 1 & Service attribute 2 & Service attribute $\mathrm{n}$ \\
\hline Abstract (AA) & Service attribute 1 & Service attribute 2 & Service attribute $\mathrm{n}$ \\
\hline $\begin{array}{l}\text { Consequences or } \\
\text { Benefits }\end{array}$ & Named value 1 & Named value 2 & Named value $\mathrm{n}$ \\
\hline Functional (CF)) & Consequence 1 & Consequence 3 & Consequence $\mathrm{n}$ \\
\hline Psychological (CP) & Consequence 1 & Consequence 2 & Consequence $\mathrm{n}$ \\
\hline Values & & & \\
\hline Incremental (VI) & Named value 1 & Named value 2 & Named value $\mathrm{n}$ \\
\hline Terminal (VT) & \multicolumn{3}{|c|}{ Named final value category } \\
\hline
\end{tabular}

Source: cf. Wansink, 2003.

Value creation by the customer is explained by hierarchical value maps, which were outputs from MECanalyst software based on the interviewee data (Figures 2 and 3). In the hierarchical value maps the cut-off levels are indicated describing the level where the content category has received fewer mentions compared to the cut-off -level. The proper cut-off -level (cut-off 1 or 4) was chosen during the analysis process. The practical guideline is that a hierarchical value map is done first by using a few cut-off levels, after a kind of level that is the best from the interpretation viewpoint is chosen (Breakwell, 2004). If the cut-off level is too low, a hierarchical value map includes so many details that interpretation becomes impossible. On the other hand, a cut-off level can be kept as low as possible so that the content message of data can be interpreted. (Leppard et. al., 2004, 493-494)

\section{Findings}

In the findings, the terminal value categories (VT) in the role of a host included the following: feeling of impressiveness (18); feeling of indulging oneself, pleasure, and joy (17); feeling of hospitality (8); feeling of healthiness (6); and feeling of beauty of nature (6).

\section{Feeling of Impressiveness from a Nature-based Service}

The highest number of the people interviewed mentioned "Feeling of impressiveness" (VT) as the final value category in the role of a host. The hosts wanted something to be told forward, such as the stories of a guide, new skills or their own good experiences. Own stories were created from memorable experiences, such as executing a reindeer driving license, listening to a life story of a fisherman, myths related to nature. An example illustrates an experience of an interviewee. 
"A friend caught a $20 \mathrm{~kg}$ salmon and called his wife that now throw away all berries from the freezer. There will be put my salmon. These kinds of stories will stay and become legends." (H10.)

By a hierarchical value map it was possible to analyse the things related to attributes, consequences and indirect value categories linking to the final value of impressiveness (Figure 2).

Figure 2. A Hierarchical Value Map of Feeling of Impressiveness in a Role of a Host

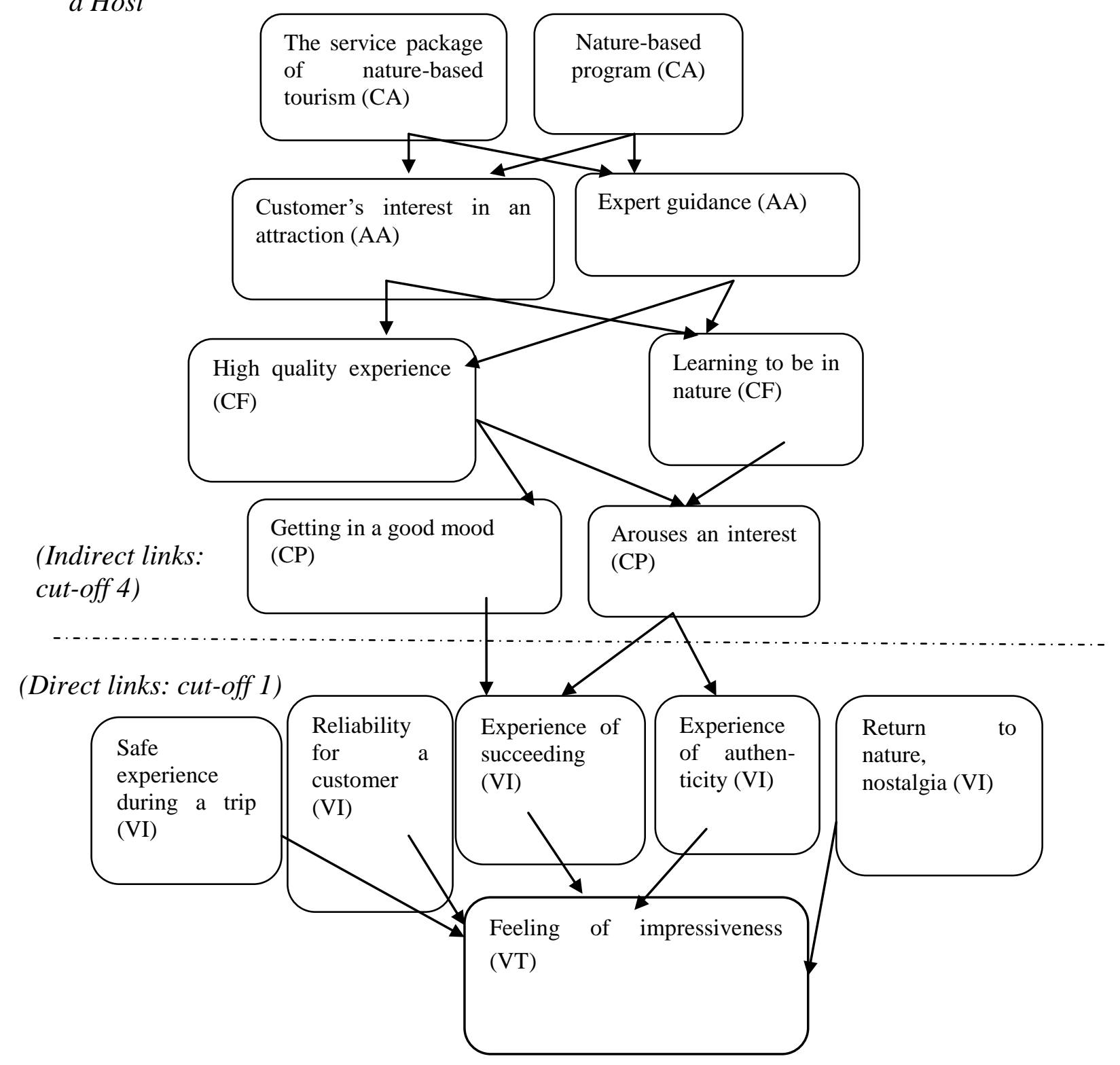

Source: Alakoski, 2014, 88. 
"The service package of nature-based tourism" formed a concrete basis of attributes, according to which the whole service package was received from the same entrepreneur. The contents of "The nature-based program" and "Expert guidance" raised their importance. Knowledge of the Finnish nature and history as well as local knowledge was required of the guides. When guiding a tourist group, communication skills and language proficiency, social competences, and discussion abilities were required.

When the value category was defined based on "High quality experience", it was combined with content messages related to keeping the schedule, organisational ability, running the program smoothly, and food quality. Using the nature-based tourism service need not be too troublesome. It was important from the viewpoint of a host to be able to participate with other participants in the program, and the host did not have to guide the group. "High quality experience" included smooth cooperation between the host and the entrepreneur during the trip.

In the content category "Learning to be in nature", losing touch with nature and learning again to be in nature were discussed. During the naturebased trip different kinds of activities were implemented compared to daily life or the town residents learned to survive. Based on the interviews, it emerged that many of those interviewed questioned one's abilities to be in nature. "Getting in a good mood" was explained, for instance, by humour, contrast or unexpected service. "Arouses an interest" was explained by surprising situations, such as seeing the cranes or other animals. Nature was also an interesting attribute for foreigners, who formed an image of Finland based on it.

The incremental value categories formed direct links to "Feeling of impressiveness". It arose from "Experience of authenticity"; "Experience of succeeding", "Reliability for a customer", "Safe experience during a trip", and "Return to nature, nostalgia".

\section{Feeling of Indulging Oneself, Pleasure and Joy as a Value Category}

As content messages of the value category "Feeling of indulging oneself, pleasure and joy" (VT) it was mentioned that "The nature-based program" provided a social atmosphere and laughter. The participant in the role of a host might forget schedules and enjoy nature and activities (Figure 3).

The feeling of pleasure also added participation in preparing food or experiencing good luck, such as catching the first fish. Nostalgic experiences remembering childhood were also included in "Feeling of indulging oneself, pleasure and joy". The next example describes pleasure.

"The program included always joking, an adult got a permission to play, to be a child. Pinstripes were taken away and leisure time apparel were put on. Everybody was allowed to be a child, to take another role. It was thrown snow balls, romped. It was entertaining to see, it was cheerful." (H40) 
Figure 3. Feeling of Indulging Oneself, Pleasure and Joy as a Hierarchical Value Map



Source: Alakoski, 2014, 91.

According to one interviewee, utilizing "The service package of naturebased tourism" was new. Different kinds of "Nature-based programs", such as a snowmobile drive, a reindeer ride, downhill skiing or a shaman evening were included when experiencing that value. This value category was linked to "Easy doing", "Expert guidance", and "Customer's interest in an attraction". A nature trip offered an easy, quick visit out of daily life. Although the participants had low level skills with respect to nature or sports, everyone had to participate in the activities in one's own style.

"Learning to be in nature" represented the functional consequences. It was linked to activities, such as skiing or snowshoe walking or learning from different kinds of activities not done in daily life. Psychological consequences were "Getting in a good mood", "Co-experience energizes", and "Receiving change". "Getting in a good mood" was often linked to guidance with stories with humour. When "Receiving change" it was emphasized that nature as an 
environment is different compared to town with its noise on the background offering counterbalance. Nature offered the natural environment to look at and for the host a special opportunity to meet customers during the trip.

The incremental value categories were linked to "Experience of succeeding", "Return to nature, experience of nostalgia", "Experience of convenience", "Safe experience during a trip", and "Experience of authenticity".

\section{Feeling of Hospitality, Feeling of Healthiness, and Feeling of Beauty of Nature} as Value Categories

To the terminal value categories experienced by a host were linked also "Feeling of hospitality", "Feeling of healthiness", and "Feeling of beauty of nature". "Feeling of hospitality" creates opportunities for the next customer appointment. It was considered important that everybody felt they had been a special guest of a nature-based tourism company and that participants were given an opportunity to succeed in performing activities during the trip. It was also made possible that a host could participate in the fun with the guests. "Feeling of hospitality" was based on especially the guide's genuine willingness to implement the service.

There was a strong link between a host's target of interest and "Feeling of healthiness". The category was explained so that exercise outside was healthy or stress was lowered during nature trips. Participating in a nature trip was preferred to restaurants with the guests. The natural environment was considered exotic, silent and clean, local food and the guide's stories strengthened belonging to the place, environment and wellbeing. A host considered it important to experiment with different kinds of activities in a nature-based environment. It was also fashionable or more acceptable to participate in a nature-based trip. Furthermore, the traditional pepper beefsteak - red wine supper was perceived as too conventional and the restaurant evenings with the guests too exhausting.

Ethical aspects related to the Finnish nature, such as cleanliness and unspoilt nature, calm, and greatness of nature were also mentioned. Many participants considered the Finnish nature, e.g. wintry and snowy nature, especially beautiful. Foreign guests' admiration increased the Finnish host's experience of beauty. Nature was experienced as a feeling of resting mind, where beauty was topmost. It was surprising for a host that he/she considered the neighbouring area beautiful in a different way with different groups. Experiences based on small things or simple being, e.g. sitting at a campfire or original atmosphere cannot be experienced in a town environment. One interviewee told about having felt the roots of the Finnish life in nature. For a host, "Experience of succeeding" was generated out of guests' enjoyment when they experienced unexpectedly the greatness of nature. 


\section{Conclusions}

As the answer to the research question, five terminal value categories (VT) were found in the role of a host of a business customer: Feeling of impressiveness; Feeling of indulging oneself, pleasure, and joy; Feeling of hospitality; Feeling of healthiness; and Feeling of beauty of nature.

Based on the findings, the theoretical contribution is how service attributes, consequences of the usage, and value categories are linked to valuein-use as perceived by a host of a business customer in the context of naturebased tourism. The business customer's value in the role of a host is understood as a long-lasting value accumulating in the host's process, and is stored in mind and memories strengthening business relationships.

For a host of a business customer, an individual experience is created, and individual value is related to emotions and meanings. Evaluation of usage experiences is created in the context of one's life. The meanings may have an impact on the buying decision in the business company.

Furthermore, the theoretical contribution is related to interaction and resources. In a nature-based tourism service the cooperation between a host of a business customer and guests is emphasized as well as interaction in unofficial situations, which helps dialogue in the future. The findings indicated, for example, new modes of cooperation, spontaneous project ideas, and followed by that, feelings about value creation and benefits for future cooperation. Also new cooperative ideas were born between the guests, who will all benefit in the future. These kinds of findings illustrate the shared value for both a host, a business company, and the guests.

A nature-based tourism service company is expected to support the success of the service, the creation of a service process for the customer, and the customer's value creation. In the role of a host the target is utility for the business and achieving competitive advantage, and at the same time, becoming a partner with the company's customers.

A customer-centered business logic is changing thinking about value creation of the customer in the nature-based tourism service context. Similarly, it is changing the thinking about combining resources and the concept of value creation as an interaction process. The terminal value categories that have emerged can act as a help when developing value propositions and service in nature-based tourism service companies.

\section{References}

Alakoski, L. 2014. The value creation of a business customer in nature-based tourism service - The service-dominant logic perspective, Helsingin yliopisto, Maatalousmetsätieteellinen tiedekunta, Taloustieteen laitos, Julkaisu numero 60. (Finnish), available at: https://helda.helsinki.fi/bitstream/handle/10138/42944/alakoski vai toskirja.pdf?sequence $=1$ (22 November 2014).

Bowman, C. and Ambrosini, V. 2010. How value is created, captured and destroyed. European Business Review 22, 5, 479-495. 
Breakwell, G. 2004. Doing social psychology research. Victoria: The British Psychological Society and Blackwell Publishing.

Fredman, P. and Tyrväinen, L. 2010. Frontiers in Nature-Based Tourism. Scandinavian Journal of Hospitality and Tourism 10, 3,177-189.

Gengler, C. E., Mulvey, M.S., and Oglethorpe, J.E. 1999. A means-end analysis of mother's infant feeding choices. Journal of Public Policy \& Marketing 18, 2, 172-188.

Grunert, K.G., Grunert, S.C., and Sorensen, E. 1995. Means-end chains and laddering: An inventory of problems and an agenda for research. European Advances in Consumer Research 2, 366-371.

Grönroos, C. 2008. Service logic revisited: who creates value? And who co-creates? European Business Review 20, 4, 298-314.

Grönroos, C. 2011a. Value co-creation in service logic: A critical analysis. Marketing Theory 11, 3, 279-301.

Grönroos, C. 2011b. A service perspective on business relationships: The value creation, interaction and marketing interface. Industrial Marketing Management 40, 240-247.

Grönroos, C. and Gummesson, E. 1985. The Nordic School of Services - An introduction. In Grönroos, C. and Gummesson, E. (Eds.) Service marketing Nordic school perspective, 6-11. Series R2, Stockholm University.

Grönroos, C. and Helle, P. 2010. Adopting a service logic in manufacturing: Conceptual foundation and metrics for mutual value creation. Journal of Service Management 21, 5, 564-590.

Grönroos, C. and Ravald, A. 2011. Service as business logic: implications for value creation and marketing. Journal of Service Management 22, 1, 2-22.

Grönroos, C. and Voima, P. 2013. Critical service logic: making sense of value creation and co-creation. Journal of the Academic Marketing Science 41, 2,133150.

Gummesson, E. 2011. 2B or not 2B: That is the question. Industrial Marketing Management 40, 2, 190-192.

Gutman, J. 1982. A Means-End Chain Model Based on Consumer Categorization Processes. Journal of Marketing 46, 60-72.

Heinonen, K. and Strandvik, T. 2009. Monitoring value-in-use of e-service. Journal of Service Management 20,1,33-51.

Heinonen, K., Strandvik, T., Mickelsson, K-J., Edvardsson, B., Sundström, E., and Andersson, P. 2010. A customer dominant logic of service. Journal of Service Management 21, 4, 531-548.

Helkkula, A., Kelleher, C., and Pihlström, M. 2012. Characterising value as an experience: Implications for service researchers and managers. Journal of Service Research 15, 1, 59-75.

Honkanen, A. 2004. Menneisyyden tulevaisuus. Postmodernit matkailuteoriat ja vapaa-ajan matkailun muutokset eräissä Euroopan unionin jäsenvaltioissa vuosina 1985 ja 1997, Keskusteluja ja raportteja, No. 5, Savonlinna: Matkailualan verkostoyliopisto.

Konu, H. 2010. Identifying potential wellbeing tourism segments in Finland. Tourism Review 65, 2, 41-51.

Leppard, P., Russel, C.G. and Cox, D.N. 2004. Improving means-end-chain studies by using a ranking method to construct hierarchical value maps. Food Quality and Preference 15, 489-497. 
Matkailun edistämiskeskus 2005. Hyvinvointi- ja wellness-matkailun peruskartoitus, No. A: 114, Helsinki. Available at: www.mek.fi/tutkimukset-ja-tilastot/ (18 September 2013).

Miles, S. and Rowe, G. 2004. The Laddering technique, 305-343. In G. Breakwell (Eds.), Doing social psychology research. Victoria: The British Psychological Society and Blackwell Publishing.

Olsen, J.R., Harmsen, H. and Friis, A. 2008. "Linking quality goals and product development competences", Food Quality and Preference, 19, 1, 33-42.

Phillips, J.M. and Reynolds, T.J. 2009. A hard look at hard laddering. A comparison of studies examining the hierarchical structure of means-end theory. Qualitative Market Research: An International Journal 12,1, 83-99.

Pieters, R., Baumgartner, H., and Allen, D. 1995. A means-end chain approach to consumer goal structures. International Journal of Research in Marketing 12, $227-244$.

Raadik, J., Cottrell, S.P., Fredman, P., Ritter, P., and Newman, P. 2010. Understanding Recreational Experience Preferences: Application at Fulufjället National Park, Sweden. Scandinavian Journal of Hospitality and Tourism 10, 3, 231-247.

Reynolds, T.J. and Gutman, J. 1988. Laddering theory, method, analysis and interpretation. Journal of Advertising Research 28, 1, 11-31.

Sheldon, P.J. 1995. The demand for incentive travel: an empirical study. Journal of Travel Research 33, 23-29.

Smith, M. and Kelly, C. 2006. Wellness Tourism. Tourism Recreation Research 31, 1, $1-4$.

Sondergaard, H.A. 2005. Market oriented new product development: How can a means-end chain approach affect the process. European Journal of Innovation Management 8, 1, 79-90.

Vargo, S.L. and Lusch, R.F. 2010. It's all B2B ... and beyond: Toward a systems perspective of the market. Industrial Marketing Management 40, 181-182.

Veludo-de-Oliveira, T.M., Ikeda, A.A., and Campomar, M.C. 2006. Laddering in the practice of marketing research: barriers and solutions. Qualitative Market Research: An International Journal 9, 3, 297-306.

Verhoef, P.C., Lemon, K.N., Parasuraman, A., Roggeveen, A., Tsiros, N. and Schlesinger, L.A. 2009. Customer experience creation: Determinants, dynamics and management strategies. Journal of Retailing 85, 1, 31-41.

Wansink, B. 2003. "Using laddering to understand and leverage a brand's equity", Qualitative Market Research: An International Journal, 6, 2, 11 - 118.

Woodruff, R.B. 1997. Customer Value: the next source for competitive advantage. Journal of the Academy of Marketing Science 25, 2, 139-153. 
